\title{
EXPRESSION OF CATHEPSIN L GENE OF FASCIOLA GIGANTICA IN DIFFERENT DEVELOPMENTAL STAGES
}

\author{
M. A. Ghoneimª, A. F. El- Ktrdasyb, Adel K. Goherc, \\ W. M. Moussad, S. S. El-Ballale, Ahmed A. Moussab
}

a) Department of Biochernistry and Cliernistry of Nutrituon. Facully of Vetertnary Medicine. Calro Undversity. b) Department of Biochemistry and Cliemsetry of Nutrition. Facrilty of Velennary Medicine-Sadal city, Minufiya University. c) Department of Clincal Pathology. Faculty of Veternary Medictne, Cairo University. d) Departmerit of Parasitology. Facully of Veterinary Medicine, Calro University. e) Department of Paltology. Faculty of Velertnary Medicine- Sedat clty, Minuflya Undversity.

\begin{abstract}
Fascioliasis is one of the most serious parasitic infestations of livestock. It is caused by Fasciola hepatica (Temperate regions) and Fasciola gigantica (Troplcal reglons).It also has a zoonotic inportance. The proteolytic enzyme; cathepsin- $L$ cysteine proteinase $(28-28.5 \mathrm{KDa})$ helps the parastte in tissue inuasion, host inmune evasion and nutrients intake. This study aimed to check weather Fascibla glgantica flukes depend upon cathepsin-L throughout thetr life cycle in snail and mammalian hosts or not. For that cathepsin-L gene was investigated in adult and other developmental stages of Fasciola gigantica using seni-quantitative RT-PCR assay. Cathepsin-L protein was detected by using sodtum dodecyl sulphate polyacrylamide gel electrophoresis (SDS$P A G E)$ analysis and detection of catheps (n-L cysteine proteinase antigen in examined stages by Enzyme linked immunotransfer blot (EITB) analysts. Stages of Fasclola glgantica were collecled from an experimental life cycle that was completed in our laboratory. The adult worms and eggs were collected from bile ducts and gall bladders, respectively. of slaughtered nalurally infected cattle at El-Shohada abattoir. Minufya Proutnce. Egypt. The results obtained reveled that cathepsin-L gene is expressed in adult and other developmental stages of Fasciola gigantica with a molecular weight of 28-28.5 kDa. These results are promising for developing an effectlve and rellable method for carly dtagnosis of Fasciola gigantica where cysteine proteinase enzyme is present in adult and other developmental stages with molecular weight at 28-28.5 kDa and its gene is fully expressed in adult and other developmental stages.
\end{abstract}

Key words: Fasciola gigantica, Cathepsin L. mRNA, RT-PCR, EITB.

\section{INTRODUCTION}

Fasciolosis is a hepatic parasitic infection caused by F. hepatica or F. gigantica that aflects numerous mammallan speeles, malnly ruminants and occasionally human. In several countrles of Europe. Asia, America and Africa. particularly in Egypt. The economlc signlficance of fasciolosis is mainly due to either 
direct losses following deereased growth rate, low milking eapaelty and the eonfiscation of altered livers in slaughterhouse (Gajewgka et al. 2005) or Indirect losses due to the Interlerence with the reproductlve efliciency as well as retardation in the growth of young antmals (Heath et al., 1997).

In human, the prescnee of adult nuke in the blle ducts causes a vartety of symptoins such as malaise. long standing fever, and weight loss, pain under the right costal inargin, eosinophilia and anaemia caused by fceding on the host blood (Soulsby. 1982].

Fascioln glgantica in Egypt was reported by Haseeb et al. (2002) who stated that it is a serious disease affcctung dimerent categorles of animals as shcep. goats. cattle buffaloes. horses, rabblts. donkeys and camels, as well as man. The world health organization revicwed the importance of human fasclollasts as a public health disease; this is due to the number of human cases recorded (about $\mathbf{2 . 4}$ million people) with liver flukes worldwide (Mas-Coma et al., 1099).

Bentancor et al. (2002) stated that cathepsin $\mathrm{L}$ proteinases ( $\mathrm{Cl}, \mathrm{l}$ and $\mathrm{CL} 2)$, are the major components of Fasclola hepatica excretion / secretion products $(E / S)$ and considered potential antigens of a vaccine agalnst fascioliasis. They analysed the humoral responsc elictted by CL1 and CL2 in rats immunized with the enzymes or infected with F. hcpatica, by examining specific IgE and IgG subclass dynamics. Moreover, Kuk et al. (2005) said that cathepsin $\mathrm{L}_{1}$ (CatLl) is onc of the major moleculcs in the excrctorysecretory products of Fasclola hcpauca and was secreted by all stages of thc developing parasitc.
Early diagnosis is not posslble because eggs don't appear in leces untll nukes reaeh maturity, usually between 8 and 12 weeks after Infeetion. The question was developed about possibility of usage of protcin antigen of F. glgantica isolate in the immunodlagnosis of the disease in human and animal which will be simple, rapid and cheap, early as possible (2-4 weeks post infeetion), more sensitive and more specific. Also, recent results from several laboratorles have demonstrated that animals can be significantly protected against infection by vaccination with defined native Fasciola antlgens, which were isolated from excretorysccretory products of the parasite, cathepsin $L$ and haemoglobin (Dalton et al., 1996) or by fatty acld binding protein and glutathlone (Spithill and Dalton, 1998). A part from reducing quke burdens, such vacclnes can elicit a concurrent reduction in parasite egg production. So there is need to develop costeffective, environmentally safe and sustalnable strategies, such as vaccination, for control of this disease.

\section{MATERIALS AND METHODS}

Lymnaea calllaudi snalls were collected from Abo-Rwash. Glza Province and reared as previously described by El-Gindy and ElGindy، 1964. Adult Fasclola gdgantica were collected from the common blle duct of naturally Infected cattle slaughtercd in ElShohada abattolr in Menofla Province. The adult flukes werc identffed, washed three times with $0.9 \% \mathrm{NaCl}$ solution and frozen in $0.9 \% \mathrm{NaCl}$ solution at $\left(-40^{\circ} \mathrm{C}\right)$ untll used for RT-PCR. Eggs of Fasciola gigantica werc collected from the gall bladdcrs of naturally inrected cattle slaughtered in the abattoir and 
prepared for RT-PCR according to the method described by Amer (1996).

For Embryonatlon of eggs, it must be as fresh as possible, so the eggs of Fasciola gigantica were collected from the gall bladilers of naturally infeeted cattle slaughtered In ElWaraq abattoir In Giza prownce near to the laboratory. These eggs were let to embryonat for Production of Miracidla in the lab accordIng to the method IIsted by (Boray, 1964). This miracidia will be used for infection of snatls.

\section{Infection of Snails:}

Inficction processes were carried out as prevously described by Abdel Ghanl, 1964. Brlenly. Lymnaea caillaudl snails were exposed Individually to the required dose of freshly hatched miraeldla by using $25 \times 30$ cm transparent plastic plates contadning 108 finger-like cylindrical depression. By using a pasture plpette. the required miracidial dose (approximately 1- $3 \mathrm{miracldla} \mathrm{/} \mathrm{snall)} \mathrm{was}$ transferred in a small drop of water to every chainber. The snalls were added direetly lone snail / chamber). The chambers were filled with dcchlorinated water. Then, the plates were covered by a transparent perforated plastic cover, and exposed to the miraeldla for 12 hours. After the exposure period. the snalls werc transferred to the plastic aquarta and labeled with the infeetlon date.

\section{Collection of Sporocyst, Rediae and Cer- carlae:}

At $10^{\text {th }}-18^{\text {th }}$ days post snalls infection. Sporoeysts were collected by removing the shells of the dead snalls, suspended in distllled water and stored at $-40^{\circ} \mathrm{C}$ unul used. At $25^{\text {th }}$ day post infection, rediae were eollected by removing the shclls of the dead snalls. suspended in distulled watcr and stored at $40^{\circ} \mathrm{C}$ untll used. Before the suspected day of shcdding (i.e., day 29), the shell of the dead snatls were removed and the ccrcarlae were collccted in distllled water. Also, after shedding. cercarlae have been eollected on aluminium foil that fixed on the wall of the aquaria at the level of the water. The eollccted cercarla was suspended in distllled water and stored at $-40^{\circ} \mathrm{C}$ until used.

\section{Preparation of total RNA:}

The total RNA was extracted using QLAG. EN, RNA extraction kit (QLAGEN., Germany). aecording to the manulacturer's instructions.

Table (1): Sequence, position primers of CL-1 gene and product size.

\begin{tabular}{|c|c|c|c|}
\hline Primer & Sequence & Position & $\begin{array}{c}\text { Product } \\
\text { Size }\end{array}$ \\
\hline $\begin{array}{c}\text { Forward } \\
\left(5^{-}-3^{-}\right)\end{array}$ & ATGACGATTTGTGGCATGAA & $50-69$ & $250 \mathrm{bp}$ \\
\hline $\begin{array}{c}\text { Reverse } \\
\left(5^{-}-3^{-}\right)\end{array}$ & GGGATACCGCGTGAGAGTAA & $280-299$ & \\
\hline
\end{tabular}

The selected CL-1, gene primer manufactured by (Metabion, Inc., Germany). 


\section{Primer Design:}

Primers were designed as shown in Tablel, based on published nucleoudes sequences (gere bank accession number u62288).

\section{Reverse Transctiptase / Polymerage Chaln Reactlon (RT-PCR):}

3 .g RNA were reverse transcriped in thermal cycler at $42^{\circ} \mathrm{C}$ lor 30 minutes by using Ready-Go RT-PCR kit. (Amcrsham, USA): A pellct that contalns all ingredients necessary for RT-PCR assay Including reverse transcriptase, RI buffer, Taq polymerasc, 20x buffer and deoxynucleotldc triphosphate mix (dNTPs). The pellet was resuspended for direct applying RT-PCR assay. The PCR contunued by heating thc samples at $95^{\circ} \mathrm{C}$ for 5 minutes for initial denaturation. The PCR will performed for 40 cycles each one composed from 3 different step; the $I^{\text {st }}$ is denaturation at $92^{\circ} \mathrm{C}$ for 1 minute, anealing step at $50^{\circ} \mathrm{C}$ for $\mathrm{I}$ minute and Extension step at $72^{\circ} \mathrm{C}$ for $1 \mathrm{~min}$ ute. The RT- PCR product was detected using agarosc gcl electrophorcsis according to Sambrook et al. (1989).

The excrctory- secretory (E/S) Products Antigen of Adult Fasciola gigantica were prepared according to Santlago de Well and tullyer (1986). While the different Developmental Stages Antigens were done as previously described by Amer (1986). The total Protein concentrations were determined by Lowry methor (Lowry et al. 1981). Each sample containing $10 \mu \mathrm{g}$ of protein was dissolved in sample buffer in ratio of $1: 2$ and bolled in bolling water bath for 2 mintutes. Samples along with prestained broad range moleeular welght proteln marker (Blo- Lab Company) werc then subjeeted to 10\% SDS-PAGE. The gel was stained with Commassle blue stain.
Proteln bands were scanned, and analyzed by densllometer to determine the molecular weights.

\section{Westem blot analysis :}

For western blotting. the proteln samples were subjected to $10 \%$ SDS-PAGE then electro-blotted onto a nitrocellulose membrane according to the modiflcd lechnlque by Towbln et al. (1979). The nitrocellulosc membranc was soaked in a blocking buffer for 2 hours and washed in washing buffer 2 tumes for 5 minutcs / each. Serum solutions were diluted in 5\% BSA in $0.3 \%$ PBST then, the nitrocellulose membrane was exposed to the dlituted sera for onc hour and washed 2-3 times for 5 minutes / each in washing buffer. then exposed to peroxidase labeled antibody diluted in 5\% BSA in $0.3 \%$ PBST for one hours. The membranc was washed $2-3$ in washing buffer and exposed to the substrate for 30 minutes. The mombrane was then rinsed thoroughly with distilled water to stop the reaction. The reaction was read by $\mathrm{Gel}$ pro-analyzer 3. I (Multimedia Co.. USA).

\section{Preparation of Hyper Immune Sera from Rabbits: \\ Six male 1.5-2 Kllogram New Zealand rab- bits were divided Into 2 groups (three rabblts for cach). Group (A): Immunlzed with purined cathepsin antigen (supplled by Blotechnology Center for Researeh and Services (BCRS), Cal- ro University, Egypt).Group (B): Injected with adjuvant alone as a control group.}

Immuntzation Protocol: (Aceording to the method deseribed by Langley and Hillyer. 1989):-

In Group (A): The anlmals were Immu- 
nized by purifled cathepsin- $\mathrm{L}$ antigen with Freund's adjuvant in ratjo of $1: 1$ (injectcd S/C in two sitcs above the shoulder at three dos. es). the 1st injection at zero day was $200 \_g$ protein of the preparcd antigen per animal which were obtained from 200 _l of the soluble extract with Freund's complete adjuvant The complete Freund's adjuvant eontainlng attenuated strains of Mycobacterium which lead to non specific immune response). The rabbits then injected with $100 \_g$ protein per animal (which were obtalned from 100 _I of the soluble extract) with Freund's incomplete adjuvant at 14 and 21 day from beginning of the experiment.

In Group (B): The animals were Injected with a dose of Freund's complete adjuvant alone at zero day $\mathrm{S} / \mathrm{C}$ in Two site above the shoulder, then the second and third doses were with Freund's incomplete adjuvant at 14 and 21 day from the beginning of the experiment, respectively. Blood samples were collected at 28 th day post immunization. Serum was prepared according to Rogan (1996).

\section{RESULTS}

\section{Gene expression analybls:}

Cathepsin L mRNA expression In Fasciola gigantlea eggs, meracidea,sporocysts, redlae .cercarlae and adult luke. As showen in fig. 1, a band of 250 bp was detected in the egg and other developmental stages. This slze is identical to that of the positive control; Fasciola gigantica DNA.

After detection of cathepsin L mRNA expression by RT-PCR, We checked Fasciola gigantica adult $E / S$ and developmental stages proteins by SDS-PAGE. The results showed expression of $28.5 \mathrm{~K} \mathrm{Da}$ proteln in all tested samples (Fig: $2 \mathrm{~A} \& \mathrm{~B}$, table 2). This indicates the presence of that protein throughout the IIfc eycle of Fasclola gigantica .

\section{Enzyme linked immunotrangfer blot} analysls (EITB):

To check weather the mRNA exprcssion of cathepthIn L is supported by protein expression. EITB analysis was applled on proteln sample from adult Fasciola glgantica (E/ S)products and olher developmental stages. Fig.3A \&B, table3 Showed that cathepsin L protein was detected as a single proteln band of $28 \mathrm{~K}$ Da in all tested samples.

\section{DISCUSSION}

Several authors have been Involved in studying the proteases durlng development of parasites sueh as the serine proteases from larvae of Hellothis virescens (Johncton et al.. 1995), the neutral proteases of the three developmental stages of Shistosoma mansonl (Aurlault et al., 1982). Enzymatlc investigatons have shown that Fasclola hepatica cathepsin $\mathrm{L}$ is expressed in different developmental stages (Carmona et al., 1993; Hawthome et al., 2000; Muharsinf et al., 2000 and Harmsen et al., 2004).

\section{Concerning Cathepsin-L mRNA Expres-} sion in Adult and Different Developmental Stages of Fasciola gigantica:

Our knowledge Indicated that there is no simliar study conducted on Fasciola gigantiea.this motivated us to perform this work on Fasciola gigantica. The present study showed the expression of cathepsin-L1 cysteine proteinase gene in adult and other developmental stages of Fasciola gigantica (eggs, miracidiae, sporoeysts, redlae and eercariae) at the expected band slze of 250 bp using RT-PCR. 
These results are in accordance with that of Tort et al. 1999 and Grams et al. 2001; Law et al. 2003 and Mohamed et al., 2005 on Fasclola hepatica.

Rcgarding Cathepsin L PTotcin Expression In adult and different developmental Stages SDS-PAGE analysts;

SDS-PAGE results showed the presence of the $28 \mathrm{KDa}$ proteln band within the protelns samples of the aduit $\mathrm{E} / \mathrm{S}$ products and the other developmental stages. These results are going with those of Smlth et al. 1993b and Dowd et al. 1994 who proved that the major protcins secreted by adult liver flukes were the 27-kDa cathepsin $\mathrm{L} 1$ and 29.5-kDa eathepsin L2 proteinases. Moreover, our findings are in accordance with that of (Fagbeml and HWlyer 1992: 8mlth et al., 1993b; Kuk et al., 2005; and Sriveny et al., 2006).

\section{EITB analgsls:}

EITB analysis in thls study showed the presence of a band of cathepsin $\mathrm{Ll}$ cysteine protcinase at $28 \mathrm{KDa}$, In adult and other developmental stages of Fasciola gigantica (eggs. miracidlae, sporocysts, redlae and eercanae).This Indicating the prescnce of cathepsin Ll protelns in these stages.

Amounts of cathepsin L proteins from EITB analysis differed from stage to stage. In eggs the amount was the lowest $(16.102 \pm g)$ then we noticed increase in the eathepsin $L$ protein in the miraeldla ( $21.878 \pm g$ ) this may explain the role of the enzyme in penetration of the snall tissues by miracidla. The amount decreascd in sporocysts $(20.826 \pm g)$ then Increased again In rediae and cercarlae $(24.765$ g. $24.069 \pm$ g. respectively). This Increase may be due to the demand of cercanae for cathepsin $L$ for facllitaung the excystation of en- cysted melaccrcarlae and penetration of the final host intestinal wall.

Another definite increase in the amount of cathepsin $\mathrm{L}$ proteins In $\mathrm{E} / \mathrm{S}$ products of adult Fasciola glgantica was noticed $(34.018 \pm \mathrm{g}$ ). This was the highest amount In all stages. This may explaln the great role of that enzyme In Fasciola glganuca adult stage elther in parasite nutrition. Ussue penetration and nnal host immune evasion.

The results obtalned in this study came in agreement with Gorman et al., 2000; Ortlz, 2000; Bossaert et al., 2000. Also Dixlt et al. 2002 discovered that the major antigenlc fraction of Fasclola hepatica ES antigen 20-30 $\mathrm{KDa}$ was recognized speciflcally by sera from F. hepatica infected calves as early as $6-8$ weeks PI.

We can conclude that Faselola glgantica parasite is eompletely depend upon cathepsin- $\mathrm{L}$ cysteine proteinases along its whole life cycle elther In snail and In mammallan host. This means that cathepsin-L eystelne proteinase is an immunodominant antigen in Fasclola gigantica life cycle. This study prediets that cathepsin-L cystelne protelnases of Fasciola gigantiea may be the most promisIng antigen for Immunodiagnosis of human and animal fascloliasis and for protection agalngt the disease through vaccination strategics.

\section{Acknowledgment:}

Great thanks to members of Biotechnology Center for Services and Researehes (BCSR), Catro University for the kind support provlded by them as apart of the project "Establishment of a new promising protoeol for production of Fasclola antigens" funded by Academy of Selenufic research and technology. 


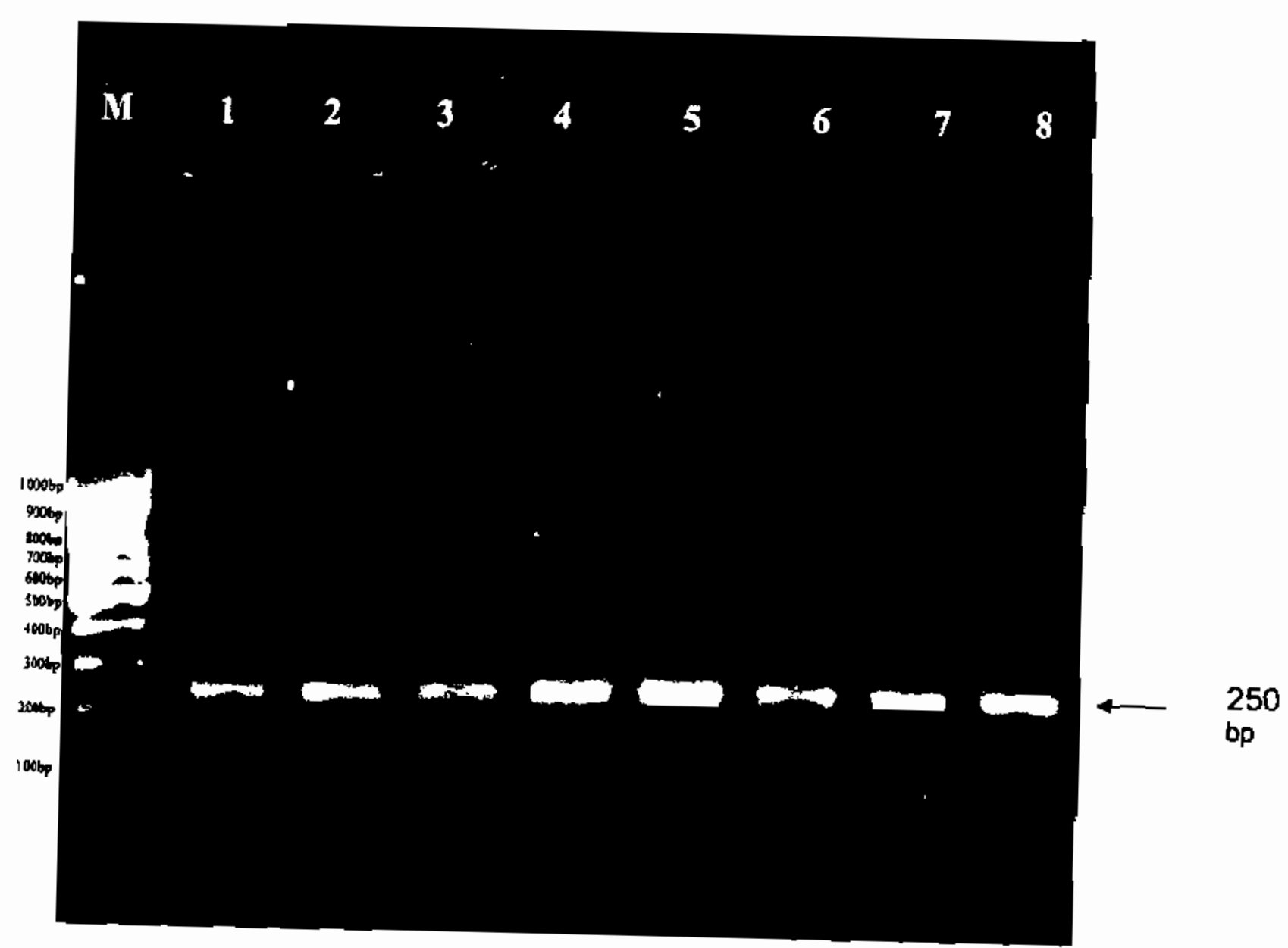

Figure (1):

Cathepsin-L1 Gene Expression Analysis Depending On Detection Of mRNA By RT-PCR Amplification Assay. Lane (1): Eggs. Lane (2): Miracidia. Lane (3): Sporocysts. Lane (4): Rediae, Lane (5): Cercariae. Lane (6): Adult. Lane (7): Adult. Lane (8): pasitive control adull Fasciola gigantica 
(A)

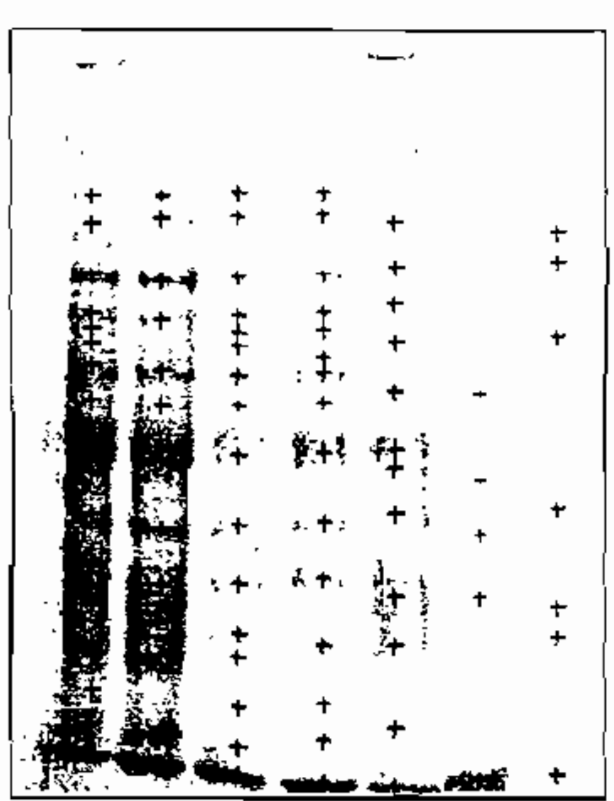

(A)

Figure (2): Coomassie blue stained SDS- PAGE of Fasciola gigantica Adult E/S products and developmental stages proteins. (A) Coomassie blue stained SDS- PAGE gel and (B) Photo of Gel pro-analyzer

$$
\begin{array}{lll}
\text { E: Egg M: Miracidia S: Sporocysts } & \text { R: Rediae } & \text { C: Cercariae } \\
\text { E/S: Excretory-Secretory products } & \text { Ma: Marker } &
\end{array}
$$


Table (2): Molecular weights and amounts of protein bands appeared in SDS-PAGE analysis of adult Fasciola gigantica E/S and developmental stages proteins.

-Amounts of protein bands in

\begin{tabular}{|c|c|c|c|c|c|c|c|c|c|c|c|c|c|c|}
\hline & Egg & & Miraci & & sporo & & Redia & & Cercaria & & $E / S$ & & Marker & \\
\hline Lanes: & Lane 1 & & Lane 2 & & Lane 3 & & Lane 4 & & Lane 5 & & Lane 6 & & Lane 7 & \\
\hline Bands & (mol.w.) & (amount)* & (mol,w.) & (amount) & (molw.) & (arnount) & (mol.w.) & (amounis & (mol.w. & (amount) & (mol.w.) & (amount) & (mol.w) & (amount) \\
\hline 1 & 140.18 & 1.5938 & 140.18 & 3.2826 & 142.04 & 1.4415 & 142.04 & 1,0021 & 121.58 & 13.033 & 56.505 & 8.2491 & 116 & 2.0841 \\
\hline 2 & $12 \mathrm{~L} .58$ & 2.2514 & 125.3 & $6 . \overline{0042}$ & $\overline{125.3}$ & 0.86246 & $127.1 \overline{6}$ & 1.2831 & 9.5 & $4 . \overline{3766}$ & $\overline{42.447}$ & 2.9478 & 97.4 & 2.1872 \\
\hline 3 & 91.4 & 4.7132 & 89 & 4.9755 & $90 . \overline{2}$ & 2.28 .587 & 91.4 & 4.3843 & 79.4 & 2.9423 & $\overline{35.191}$ & $3.4 \overline{188}$ & $66 . \overline{2}$ & 7.6514 \\
\hline 4 & 75.8 & 3.6782 & 73.4 & $3.589 i$ & $74 . \overline{6}$ & 2,3651 & 75.8 & 2.4018 & 65.231 & 3.0793 & 28.5 & 16.811 & 37.6 & 3.6273 \\
\hline 5 & 69.8 & 10.217 & 60.383 & 3.8009 & 67.4 & 4.0279 & 68.6 & 4.8514 & 56.99 & 3.1325 & 13.813 & 40.481 & 28.5 & 0 \\
\hline 6 & 65.231 & 11.796 & 54.566 & 3.4928 .5 & 64.261 & 5.3688 & $62.3 \overline{22}$ & 7.4531 & 47.28 .55 & 6.996 & & & 18.4 & 26.986 \\
\hline 7 & 61.353 & 4.4124 & 45.841 & 14.102 & $\overline{59.414}$ & $4.5 \overline{673}$ & $59 . \overline{898}$ & 7.3032 & 44.386 & 11.837 & & & 14 & 32.453 \\
\hline 8 & 55.536 & 2.8916 & 35.726 & 7.7286 & $5 \overline{4.566}$ & 1.5964 & $55.05 \mathrm{I}$ & 1.8133 & 37.065 & $8 . \overline{9441}$ & & & & \\
\hline 9 & 47.78 & 15.352 & 28.5 & 16.137 & $\overline{46.325}$ & $14 . \overline{084}$ & 46.81 & 15.43 & 28.5 & 19.443 & & & & \\
\hline 10 & 37.065 & 9.592 & 17.838 & 15.048 & 35.994 & $7.97 \overline{71}$ & $36.2 \overline{62}$ & 10.438 & 18.119 & $34.21 !$ & & & & \\
\hline 11 & 28.5 & 13.319 & $14.37 \overline{4}$ & 7.2178 & $\overline{28.5}$ & $10 \overline{846}$ & 28.5 & 13.421 & $15.4 \overline{98}$ & 0.85867 & & & & \\
\hline 12 & $18.2 ! 3$ & 13.28 .55 & & & 19.318 & $6 . \overline{7215}$ & 18.119 & 13.763 & 13.626 & 7.827 & & & & \\
\hline 13 & 16.715 & 9.0954 & & & $17 . \overline{745}$ & 17.492 & 56.153 & 3.4368 & & & & & & \\
\hline 14 & 14.749 & 8.0038 & & & 16.06 & 3.3416 & 15.123 & 67.343 & & & & & & \\
\hline 15 & & & & & 14.936 & 5.6307 & $13.7 \overline{19}$ & $11.28 . \overline{57}$ & & & & & & \\
\hline 16 & & & & & 14 & 15.6 & & & & & & & & \\
\hline
\end{tabular}




\section{Ma EIS C R S M E}

(A) $28.5 \mathrm{KDa}$. -

$+28 \mathrm{KDa}$.

(B)

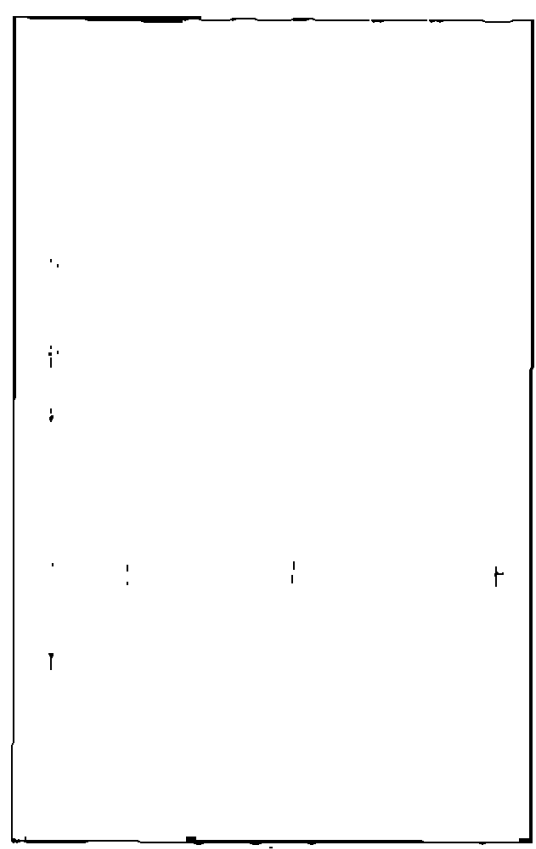

Figure (3): Immunoblotting of adult Fasciola gigantica E/S and different developmental stages antigens ( eggs, miracidiae, sporocysts, rediae, cercariae ) with cathepsin $L$ injected rabbit serum.
(A) Detection of antigens on nitracellulose sheet.
(B) Phuto of Gel pro-sualyzer.
E: Egg M: Miracidia S: Sporocysts $R$ : Rediae C: Cercariae
E/S: Excrelory-Secrelory producls Ma: Marker 
Table ( 3 ): Amounts of cathepsin L cysteine proteinase in adult Fasciola gigantica E/S and different developmental stages antigens ( eggs, miracidiae, sporocysts, rediae, cercariae ) as revealed by immunoblotting using cathepsin $L$ injected rabbit serum.

* Amounts of protein bands in $\mu \mathrm{g}$.

\begin{tabular}{|c|c|c|c|c|c|c|c|c|c|c|c|c|c|c|}
\hline & Marker & & $E / S$ & & Cercaria & & Redia & & Sporo. & & Miracid. & & $\overline{E g g}$ & \\
\hline Lane & $\begin{array}{l}\text { Lane } \\
\mathrm{l}\end{array}$ & & $\begin{array}{l}\text { Lane } \\
2\end{array}$ & & Lane 3 & & $\begin{array}{l}\text { Lane } \\
4\end{array}$ & & $\begin{array}{l}\text { Lane } \\
5\end{array}$ & & Lane 6 & & $\begin{array}{l}\text { Lane } \\
7\end{array}$ & \\
\hline Band & mol.w. & (amount) & mol.w & (amount) & mol.w & (amount) & molw & (amount) & mol.w & (amount) & mol.w & (anounc) & mol.w & $(\mathrm{amoU})$ \\
\hline 1 & 116 & 8.1562 & 28 & 34.018 & 28 & 24.069 & 28 & 24.765 & 28 & 20.826 & 28 & 21.878 & 28 & 16.102 \\
\hline 2 & $\overline{97.4}$ & 28.569 & & & & & & & & & & & & \\
\hline 3 & 66.2 & 35.661 & & & & & & & & & & & & \\
\hline 4 & 37.6 & 20.305 & & & & & & & & & & & & \\
\hline 5 & 28.5 & 33.932 & & & & & & & & & & & & \\
\hline 6 & 19.031 & 98.712 & & & & & & & & & & & & \\
\hline
\end{tabular}




\section{REFERENCES}

Abdel Ghani, A. F. (1964) : Further studles on snalls habitat. a survey of snails in the expermental flelds of Alexandrla. Pr. 6th. Ann. Vet. Cong. Fac. Of Agri.

Amer, A. S. M. (1996) : The cvaluation of different devclopmental stages of Fasclola gigantica antigens in the serodiagnosis of Fasctoliasis. A Thesis of mastcr of scicnee In Zoology (Immunoparasitology). Faculty of Scicnce, Calro Unlversity.

Aurlault, C.; Plerce, R.; Cesarl, 1. M. and Capron, A. (1992) : Neutral protcase actlvities at different developmental slages of Schistosoma mansoni in mammalian hosts. Comp. Blochem. Physlol., B 72: 377-38.

Bentancor, A; Placenza, L. and Carmona, C. (2002) : Inmunization with cathepsin L protelnases CL1 and CL2 secreted by Fasciola hepatica elicit a preferential type I response based on IgG2a antibodles in rats.J. Helmutnthol., 76 (3): 199-205.

Boray, J. C. (1964) : Studies on the rclative susceptbillty of some lymnmacids to infection with Fasciola hcpatica and Fasciola gigantica and on the adaption of Fasciola species. Ann. Trop. Merl. Parasitol. 60: 114- 124.

Bossaert, K.; Jacquinet, E.; Baunders, J. Famir, F. and Losson, B. (2000) : Cellmediated immune response in calves to single dose. tricklc, and challenge Infections with Faselola hepatica.Vetcrinary parasitology, 88: 17-34.

Carmona, C.: Dowd, A. J.; Smith, A M. and Dalton, J. P. (1993) : Cathepsin L proteinase secreted by Fasciola hcpatica in vitro prevents antibody-micdlated eoslnophll at- tachment to newly excysted juveniles.Mol. Blochem. Parasitol., 62 (1): 9-17.

Dalton, J. P; McGonlgle, S.; Rolph, T. P. and Andrews, S. J. (1996): Induction of protective Immunity In cattle against Infection with Fasclola hepatica by vaceination with eathcpsin $L$ protcinases and with hemoglobin. Infeet. Immun. 64: 5066-5074.

Dixit, A K.; Yadav, 9. C. and Sharma, R. L. (2002) : 28-kDa Fasciola gigantica cystelne protease in the diagnosls of prepatent ovine Fasclolosis. Vet. Parasitol., 109 : 233-247.

Dowd, A J.; McGonigle, 6. and Dalton, J. P. (1994) : Purffcation and characterizathon of a sccond cathepsin $L$ protelnase secreted by the parasitic trematode Fasciola hepatica. Eur. J. Blochcm., 223: 91-98.

El-Gindy, M. S. and El-Gindy, H. 1. (1064): Factors inhcrent in the egg masses of Buillnus trancatus. Bull. Of Endemlc D1s. Vol.5 (162): 75-90.

Fagbeml, B. O. and Hillyer, G. V. (1992): Partial puriffcation and charactertzation of the proteolytic enzymes of Fasciola gigantica adult worms. Vet. Parasitol. 40, 217-26.

Gajewsha, A K. Smaga-Kozlowska and $M$. Wloenlewskl, (2005) : Pathologlcal changes of Iivernfection of Fasciola hepatica. Wiad Parazytology, 51 : 115-23.

Gorman, T.; Lopez, C.; FredeB, F, and Alcaino, H. (2000) : Immunological monitoring of chemotherapeutic success in ovine fasciolosis using a semi-purined antgen of $30 \mathrm{KDa}$. Parastologla al dla. 24 (1-2): 2734.

Grams, R.; VIchast-Grams, 8.; Sobhon, P.; Suchart Upatham, E. and Vlyanant, $V$, (2001) : Molecular clonlng and eharactert- 
zation of 2 cathepsin $\mathrm{L}$ encoding genes from Fasclola gigantica. Parasitol. Int., 50: 105-114.

Harmsen, M. M.; Cornellesen. J. B.: Buljs, H. E.; Boersma, W. J.; Jeurissen, 8. H. and van Miligen, F. J. (2004) : ldentificatlon of a novel Fasciola hepatica cathepsin L protease contalning protective epitopes with in the propeptide. Int. J. Parasitol., 34 (6): 675-682.

Haseeb, A. N.; El-Shaxly, A. M.; Arafa, M. A and Morsy, A.T. (2002) : A review on Fasclollasis in Egypt..J.Egypt.Soe.Parasitol., 32(1):317-54.

Hawthorne, S. J.: Pagano, M.; Halton, D. w. and Walker, B. (2000) : Partual character1zation of a novel cathepsin b-llke protease from Fasciola hepatíca. Blochern. Blophys. Res. Commun.. 277(1): 79-82.

Heath, H.; B. L. Blagbun; T. T. Esasser: D. G. Pugh; G. Sanders; E. Sartin; B. Steele and J. L. Sartin (1997) : Hormonal nodu lation the physlological responses of calves infecled with Elmerla bovis. Journal of Veterinary Researeh, 58: 891-896.

Johnston, K. A.; Lee, M. J.: Brough, C.; Hilder, V. A. Gatehouse, A. M. R. and Gatehouse, J. A. (1995) : Protease activitics in the larval midgut of Heliothis vircsccns: evidence for trypsin and chymotrypsin-like enzymcs. Inscet Biochem. Mol. Blol. 25: 375- 383.

Kuk, S.; Kaplan, M.; Ozdarendell, A: Tonbak, S.; Felek, S. and Kalkan, A. (2005) : Fasciola hepatica eathepsin L1 from a Turkish isolate is related to Aslatic isolates. Acta Parasitologica, 50 (3): 244248.

Langley, R. 3. and Hillyer, G. V. (1889) : Detcetion of elrculating parasice antigen in murine fascioliasls by two sites enzyme linked Imirlunosorbant assay. Am. J. Trpo. Med. Hyg., $41: 472-478$

Law, R. H. P.; Smooker, P. M.; Irolng, J. A. Pledrafita, D.; Ponting. R.: Kennedy, $N$. $J$. and et al, (2003) : Cloning and expres . sion of the major seereted cathepsin B-likc proteln from juvenlle Fasclola hepatica and analysis of Immunogenicity following liver nuke infection. Infect. Immunol. 69216932

Lowry, O. H.; Rosenbrough, N. J.; Farr, A. L. and Randall, R. J. (1851): Protein measurement with Folin - phenol reagent. J. Biol. Chem. 193: 265-275.

Mas-Coma, M. S.; Esteban, J. G.: Bargas, M. D. (1899) : Epidemiology of human fasciolosis: a review and proposed new elastmication. Bull. World Health Organ., 77 : 340346.

Mohamed, S. A. Fahmy, A. S.: Mohamed, T. M.; Hamdy, S. M. (2005) : Proteases In egg, miracidlum and adult of Fasciola glgantica. Characterization of serine and cysteinc proteases from adult. Comparative BIochemistry and Physiology, Part B 142 (2005) 192- 200.

Muharsinl, S.; Sukarsih. S.; Riding. G.; Partoutomo. S.; Hamilton, S.: Wllladsen, P.; Wijffels, G. (2000) : Identification and characterization of the excretcd/sceretcd serine proteases of larvae of the old worid screw worm fly, Chrysumya hezzlana. int. J. Parasitol., 30, 705-714.

Ortiz, P. L.: Claxton, J. R.; Clarkson, M. J.; McGarry, J. and williams, D. J. (2000) : The specificlty of antibndy responses in cattle naturally exposed to Fasclola hepatica.Vet. Parasitol; 93 (2) : 121 134. 
Rogan, T. M. (1996) : Immunological analysis of parasite molecules. Analytical Parasitology (Ed.), page: 325.

Sambrook, J., Frttech. E. F. and Manlatls, T. (1989) : Molecular cloning: A laboratory manual, seeond edition. Cold Spring Harbor laboratory press.

Santlago de Well, N. and Hiwyer, G. v. (1986) : lsolation of potentlal serodiagnostic Fasclola hepatica antigens by electroelution Irom polyacrylamtde gels. Am. J. Trop. Med. Hyg., 35 (6): 1210- 1217.

Smith. A. M.; Dowd, A.; McGonigle, S.; Keegan, P. S.; Brennen, G.; Trugett, A. and Dalton J. P. (1993b) : Purlfalion of cathepsin-L like protelnase secreted by adult Fasclola hepatica. Mol. Biochem. Parasitol., 62: 1-8.

Soulsby, E. J. L. (1882) : Helminths, Arthropods and protozoa ofdomesticated animals. $7^{\text {th }}$ ed. Balliter, Tydal and Casse), London.

Pith111, T. W. and Dalton, J. P. (1898) : Progress in the development of IIver Muke vaccines. Parasitol. Today 14, 224-228.

Sriveny, D.; Ralna, O. K.; Yadav, 8. C.; Chandra, D.; Jagraw, A. K.; 8logh. M. : Velusamy, R. and Olngh, B. P. (2006): Cathepsin L cysteine proteinase in the diagnosis of bovine Fasclola glgantica Infection. Vetennary Parasitology. 135: 25-31.

Tort, J.; Brindley. P. J.: Knox, D.: Wolfe, $\mathbf{R}$. h. and Dalton, J. P. (1999) : Helminth protelnases and their assoclated genes. Adv. Parasitol. 43, 161-266.

Towbln H., Stachelln T. and Gordon $J$. (1979) : Electrophoretic transfer of proteins from polyacrylamide gels to nitrocellulose sheets: procedure and some applications. Proc Natl Acad Scl USA 76:43504354. 


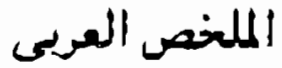

\section{دراسات جزيئية على كاثيبثن جين فى الديدان الكبدية}

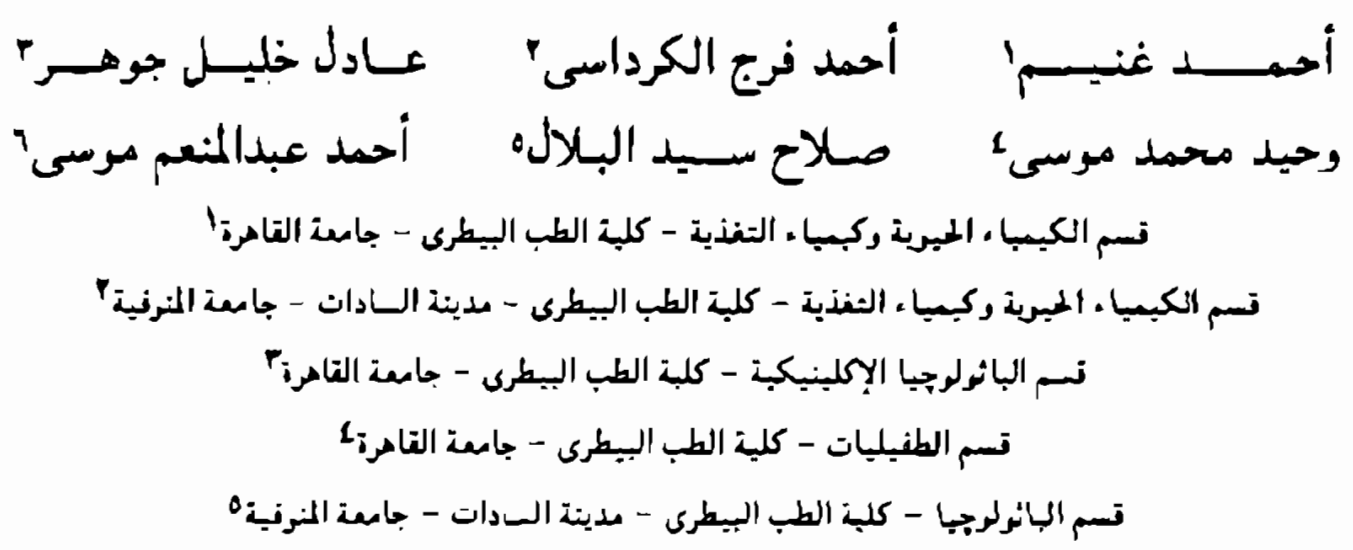

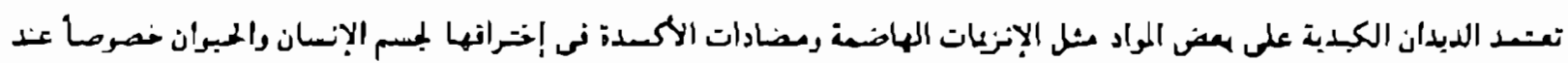

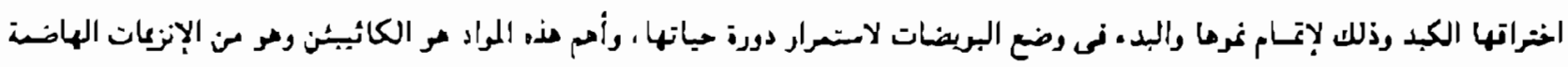

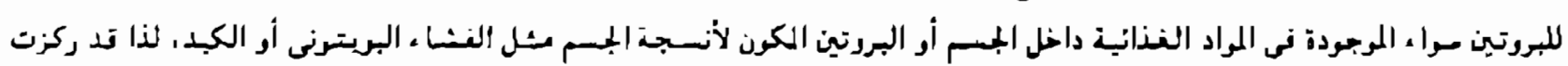

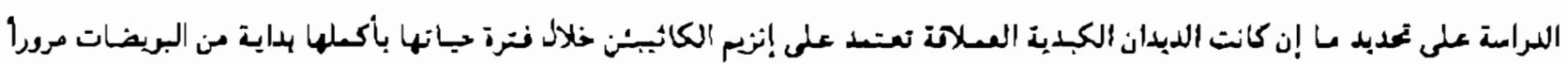

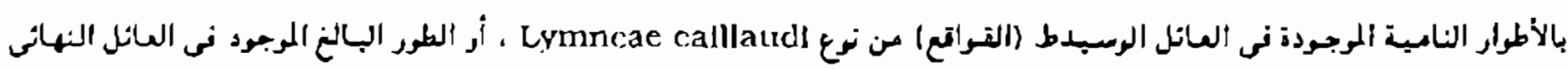

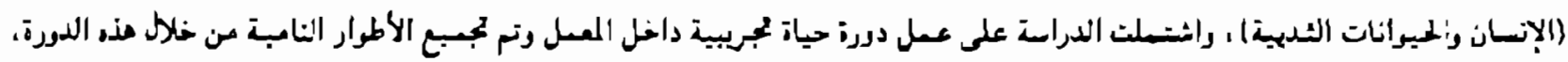

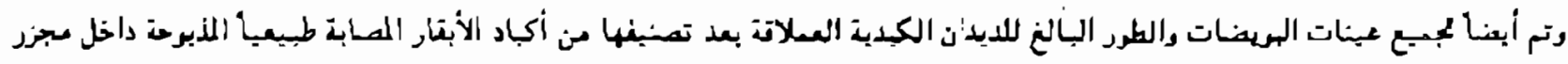

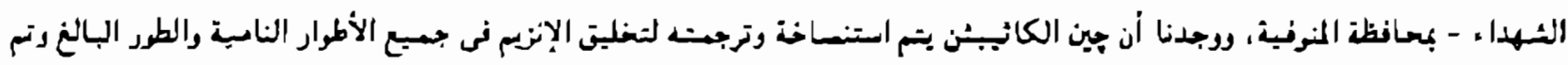

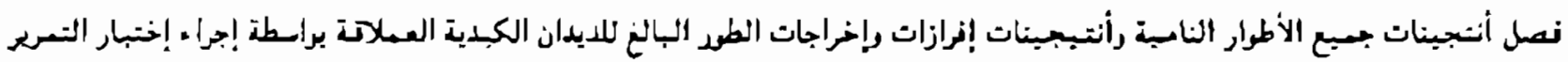

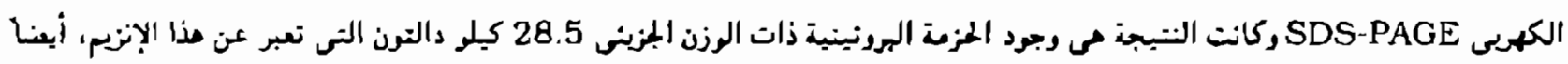

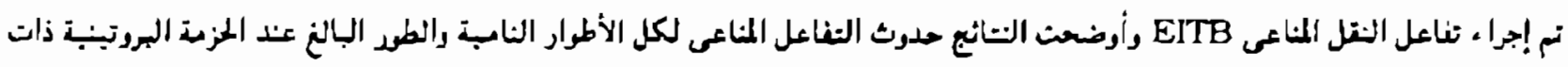

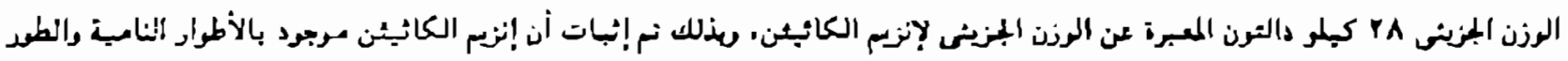

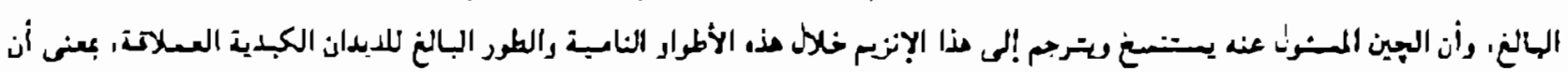
الايدان الكدية العملاكة تعتمد إعنسادا كليا على هذا الإنزي طرال دورة حياتها باكملها.

Mansoura, Vet. Med. J.

Vol. $X$, No. 2, 2008 